\begin{tabular}{|c|}
\hline MSSVD \\
President's \\
address
\end{tabular}

\title{
Sexually transmitted diseases and the Raj
}

R Basu Roy

India was the centrepiece of the British Empire, "the chief jewel in the imperial crown". After the mutiny of 1857-8 it came under direct British rule, and was a major source of national pride. Queen Victoria had an almost obsessive interest in the subcontinent. Although she never visited India herself, her various homes were full of Indian memorabilia and she employed many Indian servants, some of whom were said to exercise an undue influence on her. ${ }^{1}$ In 1876, at her express wish, an act was passed at Westminster which declared her "Empress of India". A whole department of the British government was devoted to Indian administration, and many people worked there all their lives. The military presence was strong; there were never less than 60000 soldiers of the British army stationed there ${ }^{2}$ and in addition there was a large Indian Army staffed by British officers. Many officers in the Royal Medical Corps served in India (fig 1), and other doctors joined the Indian Medical Service and worked in hospitals and academic institutes.

In the 19th century India was an unhealthy place in which to live. Malaria, cholera, dysentery, and smallpox were endemic, and there were periodic outbreaks of other infectious diseases. ${ }^{3}$ Syphilis reached the subcontinent in the 16 th century and soon became widespread. Sexually transmitted diseases (STDs) have always been a problem in armies and by the middle of the century it became clear that the army in India was severely affected. In many of the principalities the average annual admission of British troops to hospitals for venereal infections, predominantly syphilis and gonorrhoea, was over 200 per 1000; by 1895 this reached over 500 per $1000 .{ }^{4}$ In those days treatment was usually prolonged, and the loss of effective manpower was enormous. The authorities were seriously concerned. One viceroy, writing to the secretary of state for India, acknowledged that "the strength of the British Army in India as a fighting machine has been much impaired by these diseases".

The explanation of the problem seemed obvious at the time. The majority of British soldiers were aged less than 30 years; most were unmarried, and those who were married had left their wives at home. The men were inexperienced, in unfamiliar surroundings, and often underoccupied and bored. Recourse to prostitutes, the source of infection, was inevitable and understandable. Among Indian soldiers the reported incidence of venereal diseases was lower; in 1866, for example, the rates of infection for British and Indian troops were respectively 218 and 54 per $1000 .^{5}$ The doctors did their best to explain this difference away. It was suggested that native troops concealed their condition or resorted to quacks, or possibly, that they had become partially immune through frequent exposure. Nobody would entertain the idea that Indian soldiers might be less promiscuous than the British.

The management of STDs was the responsibility of medical officers in the Royal Army Medical Corps. It usually required inpatient

\section{Royal Bournemouth Hospital, Bournemouth BH7 7DW \\ R Basu Roy}

Accepted for publication 24 October 1997

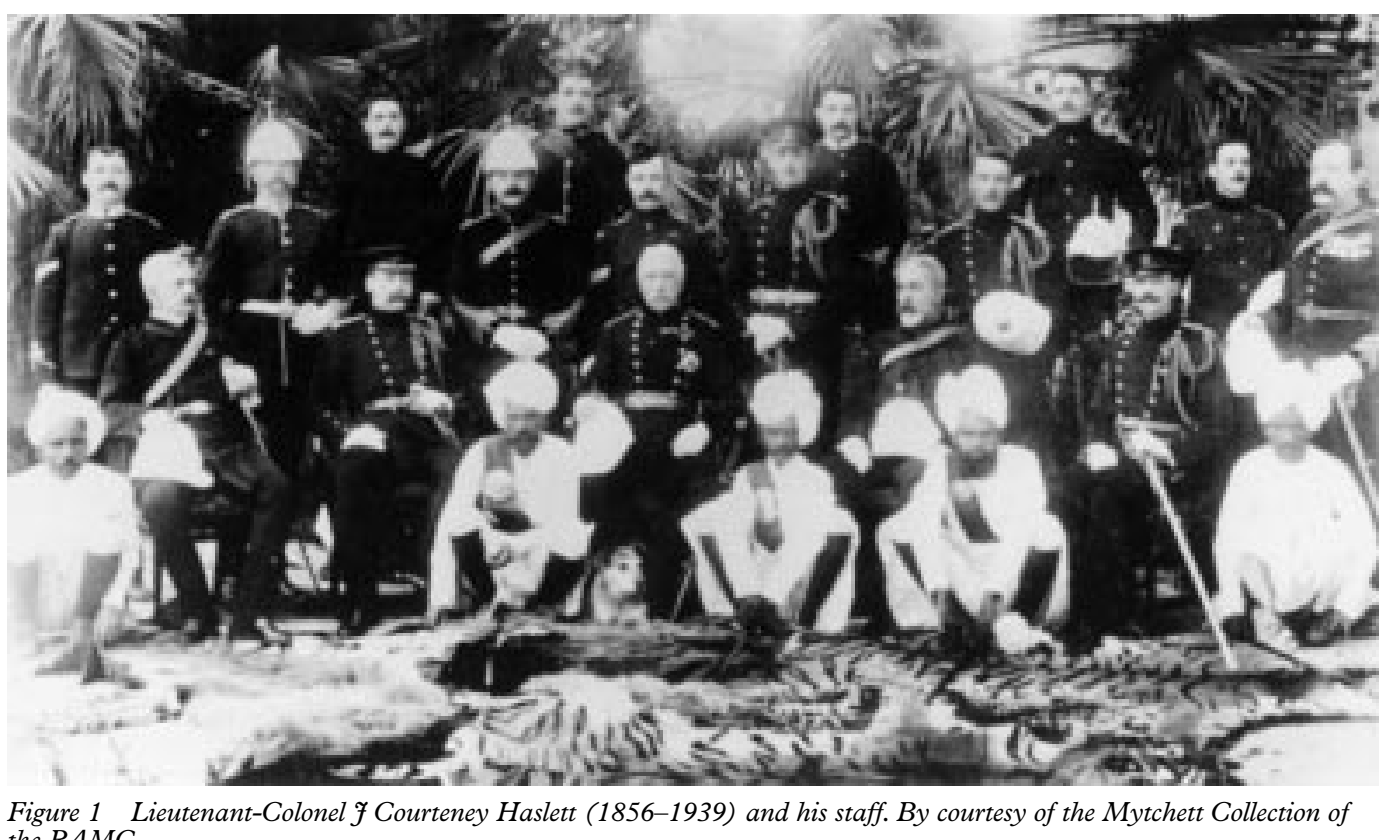

the $R A M C$. 
treatment which was provided in the hospitals attached to cantonments (permanent military stations). There were no specialist venereologists in India before 1910, but there was an army adviser who laid down treatment schedules, and special wards were provided for "difficult cases" in military hospitals in Britain. Because of the time taken to travel from India, these difficult cases were predominantly men with postgonococcal urethral strictures and late syphilis; acute complications of STDs were treated locally. There had been lock hospitals in India since 1805 , but these were intended for the treatment of infected prostitutes and for those who were the victims of venereal insontium, syphilis among the innocent; they were not patronised by the military. After the first world war special centres for the treatment of STDs in the armed forces were opened throughout India, staffed by service medical officers who had received special training in venereology. There was a consultant venereologist in Delhi, and four expert advisers in venereology attached to large centres, who performed clinical as well as administrative work. ${ }^{6}$

In the official statistics venereal diseases were classified as syphilis, gonorrhoea, and soft chancre (now called chancroid); some units added "extras" like bubo, genital abscess, phimosis, and so on. The commonest diagnosis was gonorrhoea, followed by chancre, then syphilis. For unexplained reasons syphilis was relatively more common, and gonorrhoea less common, in the Indian army than in the British army in India. Until well into the present century diagnosis in India was clinical. In the case of male gonorrhoea this did not matter much, but a clinical diagnosis of gonorrhoea in women is a shaky proposition. Although the gonococcus had been discovered in 1879, the examination of stained smears did not come into general use until the turn of the century. Harrison $^{7}$ recorded his examining cervical smears from prostitutes in India in 1903, but he had been trained as a bacteriologist. It was too much to expect station medical officers to undertake this then. Culture of Neisseria gonorrhoeae as a diagnostic aid was little used in Europe at this time, and not at all in India. Dark ground microscopy and the Wassermann reaction were available after 1906 , but technical problems and poor microscopes delayed their use in the army.

Eventually, when proper training of venereologists began in around 1910, microscopy and serology came into general use throughout the Empire. Before this, many cases of early syphilis were either diagnosed as chancroid or missed altogether. To settle the diagnosis, atypical cases were sometimes left untreated to see whether or not they developed secondary syphilis. ${ }^{6}$ This unsatisfactory practice was also sometimes used in Britain. The diagnosis of chancroid was, as so often before and since, often dubious; many men with this diagnosis actually had syphilis, herpes, phagedaena, or other kinds of ulceration. Non-gonococcal urethritis was common, but was not recorded in official statistics.
Treatment of STDs in India followed the methods used in England. Since the 18th century gonorrhoea had been treated with urethral lavage. In India, various urethral antiseptics were used; in the early days astringents such as alum or zinc sulphate were favoured, but these were replaced by silver nitrate or organic silver salts. Some of these were intensely irritating, and no doubt caused many cases of epididymitis and urethral stricture. At the end of the century, Janet's method of urethral irrigation with large amounts of dilute antiseptic solutions was adopted in Europe and, soon after, in India. The antiseptic was a matter of choice. A senior colleague told Harrison ${ }^{7}$ that "it did not matter what lotions one used, as long as one did not forget the water"; in the end, potassium permanganate was most often used. The apparatus for the irrigation varied between units and some had a distinctly homemade look. Nevertheless, lavage was thought to be effective, and it stayed in use until the advent of sulphonamides in the late 1930 s, and penicillin in 1944.

The mainstay of the treatment of syphilis in the 19th century was mercury. In India, mercurial preparations had been in use for years for the treatment of many non-venereal complaints, and its side effects were well known. In the case of syphilis, the army authorities did not like oral treatment with mercury compounds because of gastrointestinal side effects and the difficulty of securing compliance. Inunctions were ruled out as too labour intensive and in the end, a course of injections of mercuric chloride or calomel was recommended, although they were painful. In 1903 the expert adviser to the army at the time proposed repeated injections of "mercurial cream", also known as "grey oil", a suspension of metallic mercury in oil and fat which had been devised by Lange in Vienna in 1887. This was alleged to be less painful and it remained in use until the advent of organic arsenicals after 1910. Courses of treatment were supposed to last for two years, but there were administrative problems in maintaining these in men who were from time to time posted to other stations, or indeed sent home. Unless "destructive" lesions were present soldiers under treatment could, after the first few injections, perform ordinary duties, but they were not allowed to take part in active service. The results of even a course of mercury treatment considered to be optimal were disheartening. Harrison noted that $83 \%$ of a group of 371 soldiers had clinical relapses - some actually occurred during the course of treatment. Furthermore, in some stations men with syphilis did not receive the recommended course of treatment, but only a few doses of oral mercuric chloride. There can be no doubt that in the army in India many men with syphilis were seriously undertreated. As a result, destructive lesions due to late syphilis were not uncommon, particularly affecting the face, mouth, and nasopharynx. Such patients were often seen in the syphilis wards of the military hospital at Netley, in Hampshirewards which were known as "the inferno". In an official report Lord Onslow described the 
arrival of these men who had endured a long journey from India in a troopship in these words:

"Before reaching the age of 25 years these young men have come home presenting a truly shocking appearance. Some lay there having obviously only a short time to live; others were unrecognisable from disfigurement by reason of the destruction of their features, or had lost their palates, their eyesight or their sense of hearing, others again were in a state of extreme emaciation, their joints being distorted and diseased.

"Their friends and relatives refuse to receive them, and it is inexpedient to discharge them only to seek the asylum or the poor-house, so they remain at Netley in increasing numbers which, as matters now are, seem likely to continue to increase".

The reasons for this almost medieval situation affecting these "guardians of Empire" were much discussed. One suggestion was that syphilis contracted from Asian women was more severe than that contracted in Europe, but this is unlikely. It is far more probable that these awful results were primarily due to poor treatment, perhaps aggravated by mercury poisoning and secondary phagedaena. Another result of inadequate treatment may well have been aortic aneurysm. In 1876 Welch, an army pathologist working at Netley, noted that this disease was not uncommon in old soldiers, and he emphasised its association with a history of syphilis.

Arsphenamine was introduced by Ehrlich in 1910. In India, as elsewhere, the first results were excellent-much better than anything achieved by mercury. By the time of the first world war a course of treatment by multiple injections of arsphenamine, spread over many months and usually combined with intermittent injections of mercury cream, was recommended in the army. Because of the importance of returning men to duty as soon as possible, there was a tendency in India to shorten the duration of treatment; the same thing happened in Europe during the first world war, with the inevitable result that the relapse rate increased. Throughout the duration of the Raj, the treatment of chancroid remained unchanged, consisting simply of regular bathing of the ulcers with antiseptic solutions. Inguinal abscesses were treated by free incision and scraping of the cavity; this was followed by daily dressings, which kept patients in hospital for weeks on end. During the 1914-18 war, apparently at the instigation of Harrison, this was replaced by aspiration of the buboes, which gave much better results. Phagedaena was a dreaded complication of chancroid, most often seen in men with phimosis, or whose ulcers had unwisely been cauterised. ${ }^{10}$

\section{STD in the civilian population}

It has been difficult to determine the extent of STDs in the Indian civilian population because of a complete absence of data. The authorities' concern related entirely to its effect on the army, and on the prostitutes associating with it.
Careless assumptions were made, for example by Lord Kitchener, commander in chief in India before the first world war, who wrote in a memorandum to his troops in 1905 that "the common women, as well as the regular prostitutes in India, are all more or less infected with disease." "This, and frequent references to "lax native morals", typified official attitudes. There were few services for treatment of the Indian civilian population. There were no dedicated STD clinics, and patients depended on hospitals and dispensaries for treatment. As in Europe, this was only reluctantly given, and Ayurvedic treatment with traditional medicines was widely used. There seems to have been little concern about infected men, but there was pressure from women's groups in England to give help to infected women, in which Mary Scharlieb was most active. ${ }^{11}$ She was a remarkable woman who had worked for some time in India before becoming a consultant gynaecologist in London. Her experience in both countries had led to her concern about the effects of venereal diseases on women's health. She was a member of the Royal Commission on Venereal Diseases which reported in 1916. Her anxiety was shared by pioneers working in charitable institutions funded from Britain, who reported that in some major Indian cities there appeared to be alarmingly high levels of STDs in women and children, leading to many obstetric and gynaecological problems. ${ }^{5}$

Although chiefly concerned with the situation in Britain, the royal commission had an effect elsewhere. It had proposed a service which was intended to act as a role model. In India, some STD clinics were opened in a few of the major cities, but much of their work was of poor quality. Shortage of funds meant few laboratory tests, and treatment was far from ideal. It is not surprising that this happened. India was plagued by many life threatening diseases, and as in most other countries, STD services had a low priority. In both the British and Indian armies there were strong reasons to reduce the incidence of STD and return its victims to duty as soon as possible, but the motivation to provide a comparable service for civilians was absent. Then as now, wealthy people were able to bypass the system and buy services which were simply unavailable to the majority.

\section{Control of STDs}

During the 19th century attempts to control STDs centred on the control of prostitution, its assumed origin. The policies adopted in India cannot be considered separately from those in Britain. For the first half of the century there were campaigns in Britain for moral purity, and attempts were made to force the government to change the law to favour the repression of prostitution. ${ }^{12}$ These were unsuccessful, because neither the government nor magistrates were willing to restrict the sex market. By 1850 new proposals were emerging, from people who maintained that since prostitution could be neither abolished nor suppressed it should be treated as a public health problem. Zealots like William Acton $^{13}$ favoured the continental 
system of licensed brothels under close police and medical supervision. This was widely regarded as conniving at immorality, and was therefore unacceptable. A compromise was reached because of official alarm about the high prevalence of STDs in the army. Not only was this affecting its military efficiency, but soldiers returning from overseas, particularly India, were liable to infect their wives, or seaport prostitutes. The contagious diseases acts were promulgated between 1864 and 1869. They ensured that in garrison towns and major ports, women named to the police as prostitutes had to undergo a regular medical examination. If found to be infected, they were confined to a lock hospital for up to three months for treatment, after which they were regarded as cured. A routine examination of servicemen for evidence of infection would have been useful because, even without laboratory tests, many STDs are easier to identify in men than in women. However, this was ruled out on the grounds that it would destroy the men's self respect. ${ }^{14}$ The legislation concerning prostitutes was violently opposed by emergent women's groups. They particularly objected to compulsory internal examination, which was often far from being private or confidential, and they regarded speculum examination as tantamount to assault-as indeed it often was-because many doctors then did not know how to pass the instrument. Proposals to extend the legislation to industrial towns in the north of England came to nothing and the acts were repealed after 15 years, having had little effect on limiting STD in servicemen.

Efforts at control in India proceeded in parallel with those in Britain, but were more rigorous. Their sole object was to protect soldiers, and again they were centred on prostitutes. Well before the imposition of direct rule there had been local enactments requiring the women to undergo periodic examination in a lock hospital and treatment if they were infected. These arrangements were erratic, because lock hospitals opened, closed, and reopened at the behest of local authorities according to their finances and the whim of medical officers. After further legislation in 1864 the system became more secure. The Indian Contagious Diseases Act followed the lines of the British legislation, but was more strict, at times coming close to the ideas of Acton. At first it was intended to regulate the sex trade in towns where there were cantonments, but another act four years later extended its provisions to all major ports and cities. Indian prostitutes were segregated in special enclosures called chaklas within the cantonments, where there was usually a lock hospital. In some areas cantonment magistrates brought pressure to bear on women to leave their own houses and move into these quarters. A prostitute wishing to take up residence in a chakla had to apply for permission to be placed on the register of prostitutes. She was then sent in charge of the police to the lock hospital for examination before consent was given. Registered prostitutes in chaklas were called Lal Kurti, “queen's ladies". The chaklas were supervised by mahaldarnis, appointed by the government. These could be male or female, and were responsible for the women's management and behaviour. They were also required to act as pimps and provide women for the use of soldiers at the request of their commanding officers.

The Indian contagious diseases acts were attacked in both India and Britain. As in Britain, there was particular objection to examination by speculum. It was wrongly alleged by the authorities that in India such examinations were regarded with nonchalance and "offend no native susceptibility". ${ }^{5}$ A further assumption was made about the women themselves. Whereas in Britain prostitutes were regarded as women who had fallen from something better, so might be open to redemption and reform, in India they were seen as having voluntarily chosen the "oldest profession"; it was a caste occupation, often handed down from mother to daughter. Prostitutes might be cured of infection, but there was no possibility, or wish, for any change of life style. ${ }^{15}$ It is difficult to reconcile such statements with the observation, made on many occasions, that natural disasters such as floods, famine, and so on led to an exodus of young women from rural areas to cities, where they took to prostitution because they had no other source of livelihood.

As a result of public agitation, particularly from women's groups in Britain, the Indian contagious diseases acts were repealed in 1888 . Registration and licensing of prostitutes, the old rigid, lock hospital system, and even the hospitals themselves were abandoned. The result might have been predicted. To everybody's dismay, levels of infection began to rise. The army was most reluctant to abandon all controls, ${ }^{16}$ and a series of cantonment acts from 1889 onwards retained many of the features of the earlier legislation, including regular medical examination of prostitutes. Hospitals had been opened for the treatment of infectious diseases which were a danger to public health, such as smallpox and cholera, and STDs were included among these. Infected women were retained for treatment, as they had been in the lock hospitals.

As an epidemiological measure, the Indian contagious diseases acts and their successors must be judged as a failure, because the measures were directed at only one sex. As long ago as 1864 it had been noted that "however efficiently the regulations as regards women may be carried out, their success in arresting the spread of disease must be very imperfect unless similar precautions be adopted for preventing the men from carrying infection to the women". ${ }^{17}$ But the army steadfastly refused to consider any routine examination of men until the first world war, when in some units medical officers examined men for signs of infection when they returned from leave. Contact tracing was impossible in the circumstances prevailing in India. Soldiers, if they could remember who their consorts had been, refused to name them for fear that they might be unregistered prostitutes, in which case they 


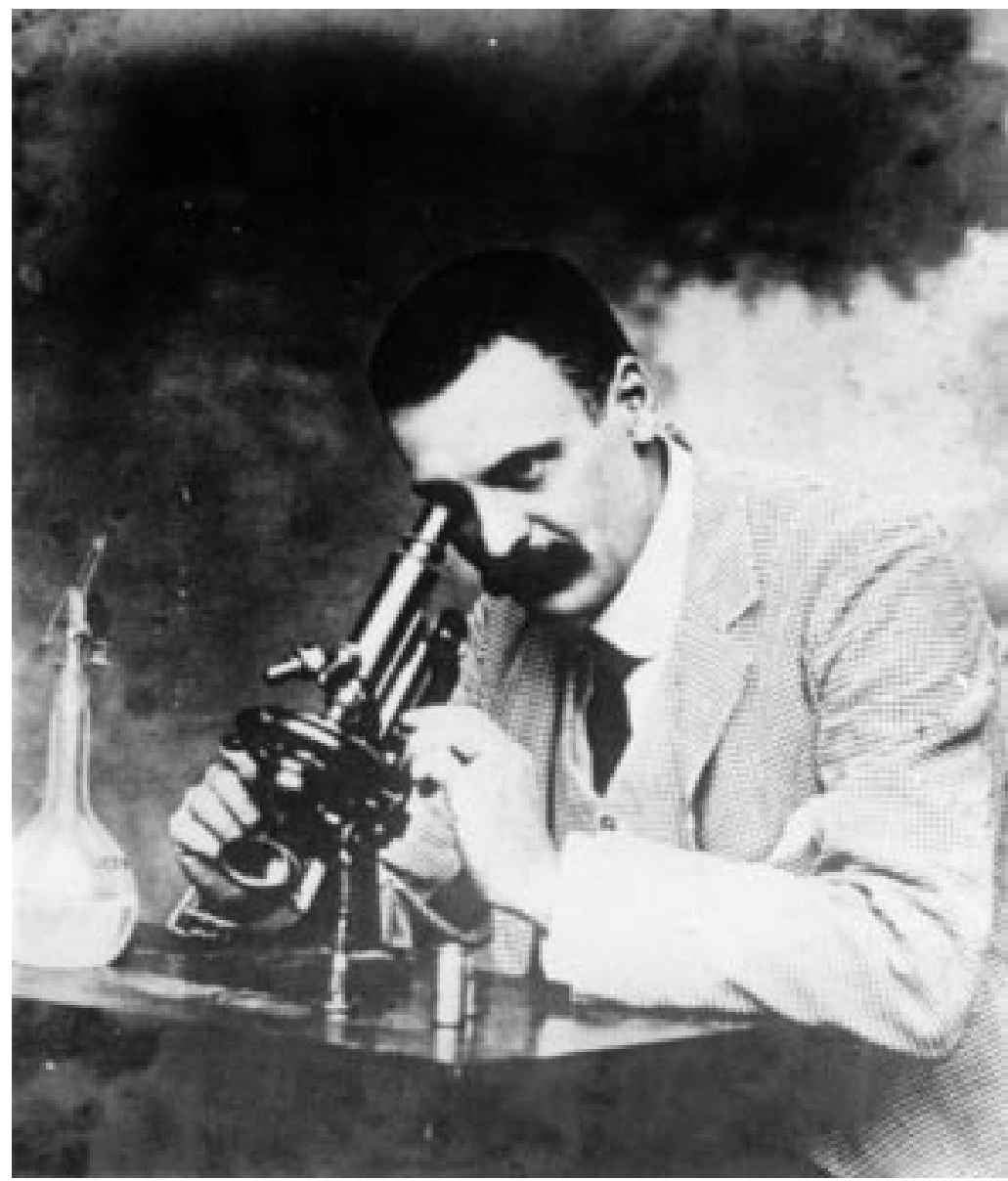

Figure 2 Donovan.
After 1900, levels of STDs in the army in India began to fall. Among the reasons were better treatment for syphilis; prolonged outpatient therapy reduced the number of relapses and readmissions, particularly after arsphenamine became available in 1910. Health education was beginning, and there was more emphasis on the provision of sport and other recreations. Personal prophylaxis was a contentious subject then, which was not mentioned in a long account of "methods of prevention" in an RAMC manual on venereal diseases published in $1907 .{ }^{18}$ It was known that if, soon after intercourse, a man washed the genitals with soap and water and applied calomel ointment to the whole area, the chances of STD, particularly syphilis, were greatly reduced. Later, a phial of a permanganate solution or silver salt for instillation into the terminal urethra was added. So called "prophylactic packages" with the necessary materials for use before and/or after intercourse could be issued. Those who saw this as a useful piece of preventive medicine were violently opposed by those who saw it as a simple incitement to immorality. However, during the first world war the use of "packets" was eventually authorised. In India the free distribution of "preventive appliances" was allowed for British forces, although not for Indian ones. In 1916 "venereal ablution rooms", where this post-coital prophylaxis could be performed under supervision, was established in all the larger units throughout the British army; soldiers who had risked infection were required to attend for treatment within 24 hours.

would be punished. Traditionally, the military authorities had accepted that an outlet for their soldiers' sexual energy was essential. The provision of women-registered, inspected, and available - was seen as a preferable alternative to masturbation or particularly homosexuality, which was dreaded. But the women had to be presentable. An "infamous memorandum" of the $1880 \mathrm{~s}^{5}$ recommended the provision of pretty women for the troops, who were disinclined to visit "hags"; these could be left for the Indians in bazaar brothels. In effect, the British authorities were conniving at a system of licensed brothels which had been specifically rejected at home, resembling the French maisons tolerees. Their justification was that they were solely concerned with the welfare of their soldiers. A few senior officers, Kitchener was one, adopted a different, sternly moral approach. Soldiers under his command were punished and held to public ridicule if they became infected, although enlightened people knew that this encouraged concealment and delayed treatment. It has been pointed out ${ }^{5}$ that the colour of the Indian prostitute, subservient to the British male, was a paradigm of racial superiority. In this regard, the presence of European prostitutes was unnerving, with the dismaying possibility that some of these women might have sex with Indian men. The British authorities resolved the problem, at least in their own minds, by letting it be known that most European prostitutes working in India were Roman Catholic or Jewish emigres from eastern Europe, and that none was British.

\section{Academic aspects}

Research in medical science in the Raj was conducted in academic institutions, some of which were established early on; for example, Madras Medical College, a medical school associated with Madras General Hospital, was founded in 1835. Doctors in the Indian Medical Service found abundant clinical material, particularly in tropical diseases, and many valuable observations were made. Ronald Ross received a Nobel prize for his work on malaria, which was partly conducted in India. The discovery of the cause of kala-azar was the work of two Irishmen in the Indian Medical Service, William Leishman in Calcutta and Charles Donovan in Madras (fig 2). They described the intracellular forms of the parasite now named after them, Leishmania donovani; Leishman was later knighted and became director of the Indian Medical Service, but Donovan remained professor of physiology in Madras Medical College. A series of discoveries about the disease now called donovanosis, formerly granuloma inguinale, were also made in India. It was first described in 1881 by Kenneth MacLeod, a Scot, who joined the Indian medical Service and became professor of surgery in Calcutta. ${ }^{19}$ Its cause was found by Donovan. In 1905 he described the intracellular bodies which now bear his name. ${ }^{20}$ The nature of these was disputed from the beginning. Donovan himself thought they were protozoa, but they were subsequently recognised as bacteria. The 
natural history of donovanosis and its probable venereal nature, was subsequently elucidated by others. ${ }^{21}$ This work seems to have been the only major contribution to academic venereology to come out of India in the days of the Raj. But it must be remembered that this was not a great period for research into STDs in Britain either. The transforming studies in bacteriology were coming from France and Germany, which makes Donovan's achievement all the more remarkable.

Medical journals in India had a long history. The Indian fournal of Medical Sciences began publication in 1834, and the Indian Medical Gazette in 1866. Many others followed, which included occasional case reports and comments on STD. The first journal devoted exclusively to the subject was the Indian fournal of Veneral Diseases, which first appeared in 1935.

\section{The later years of the Raj}

The progressive decline in STDs in the Indian armies recorded during the first decade of the 20th century was reversed during the first world war and in the years immediately following. In 1912 the admissions to hospital for the treatment of venereal diseases were 52.0 per 1000 of strength, but by 1921 the figure had risen to $110.4 .^{22}$ Such figures are not surprising, because the incidence of STDs always increases during the unsettled conditions of war and its aftermath. By 1923 the levels of infection had reduced by $50 \%$, due in part to the improving organisation of social hygiene and prophylaxis. ${ }^{23}$ The proportion of syphilis to gonorrhoea was much higher in Indian than in British troops; this had been noted before the war, and was now attributed to the fact that Indian soldiers made little or no use of prophylactic treatment rooms, such treatment being particularly effective against syphilis. During the interwar years STDs in the British army in India showed a continuous fall ${ }^{22}$; brothels were not out of bounds, although it was almost impossible to enforce this rule.

The second world war, 1939-45, saw the return of the problems of $1914-18 .^{24}$ Among British troops the rate of admission to hospitals for the treatment of STDs had been increasing since 1936, and it continued to rise, from 43.5 per 1000 in 1938 to 79.8 in 1945 . Among the reasons was the poor use of preventive procedures. At the outbreak of the war, only one "packet" per man per year was issued, and although early treatment centres were fully operational in all units, it was believed that $50-80 \%$ of infected men had not attempted to use them. Past experience had been that there was relatively less cause for anxiety about STD in Indian troops in comparison with the British, but this assumption was now incorrect; the rate per 1000 increased from 8.5 in 1939 to 46.6 in 1946. Again, the army authorities were seriously concerned, and many conferences were held. Propaganda was more vigorous than it had been; there were appeals for morality, medical officers gave lectures (reported as "bloodcurdling" by those who attended them), posters were erected, and films shown. If the worst came to the worst, it was the duty of soldiers to take precautions by using condoms, "packets", or ablution rooms. The success of these measures clearly depended on the vigour with which commanders applied them. Unfortunately, until late in the war, service amenities in India lagged far behind those in other theatres of operation. ${ }^{7}$ On the other hand, facilities for the treatment of the common venereal infections were much improved. Special treatment centres, staffed by fully trained medical and ancillary personnel, were established throughout India, and it was not necessary for patients to travel long distances to get expert advice.

The civilian population was badly served by the Raj. Narayanrao wrote in 1935: "To quote from figures available in this country is to quote nothing. Most of the people have a hatred for hospitals and clinics, because of the highbrow, indifferent and unsympathetic attitude adopted by the majority of these hospitals towards the poorer classes. This keeps the majority of patients away from them" ${ }^{25}$ In any case, as had happened in England in the 19th century, hospitals often preferred to have nothing to do with STDs. Clinics for the treatment of these diseases were almost non-existent. As late as 1933 there were no organised facilities in Calcutta, India's largest city, and in Bombay, where it had been found that $30 \%$ of people admitted to hospital were infected with syphilis, there was only one STD clinic. $^{25}$ In 1946 Prebble commented that there were very few clinics on the whole of India where patients with STDs were treated adequately, and indeed most seemed to be serving "little or no useful purpose." There were exceptions. Ceylon, which had never experienced such high levels of infection as India, had had an up to date venereal disease control scheme, run on British lines, since 1938, but perhaps inevitably these services had broken down by the end of the second world war owing to inadequate funding from the local health department and lack of personnel. ${ }^{26}$

In 1947 India achieved independence. With it came the departure of the British army and its elaborate system for the control of STDs. Some of this passed to the Indian army, but the facilities for the general population remained very poor. The new Indian government accorded STDs a low priority among the many health problems with which it had to contend, and a central venereal disease authority was not established until 1957. ${ }^{4}$ This meant that the service developed slowly, and was ill prepared for the escalation of AIDS in the late 1980s. The history of this catastrophe has yet to be written.

Author's note. This is an expanded version of a presidential address given to the Medical Society for the Study of Venereal Diseases on 25 April 1997. The author was the first Indian President of the Society.

I should like to acknowledge the kindness of many people who have helped me with information, illustrations, and documents They include Drs R S Morton, R N Thin, J D Oriel, J S Bingham, Col John Richardson, (RAMC), librarians of Hastings Library (BMA), RCP Edinburgh, and the Wellcome Institute.

1 Reid M. Ask Sir Fames. London: Hodder \& Stoughton, 1987:128-57.

I


2 Spiers EM. The army and society. London: Collins, 1980:135. MacGregor WL. Practical observations on the principal diseases affecting European and native soldiers in the north west provinces of India. Calcutta: Thacker, 1843:xi-xii.

4 Arnold D. Sexually transmitted diseases in nineteenth and twentieth century India. Genitourin Med 1993;69:3-8.

5 Levine P. Venereal disease, prostitution and the politics of Empire: the case of British India. 7 Hist Sexuality 1994;4:579-602.

6 Prebble EE. Venereal disease in India. Br f Vener Dis 1946 : 19:55-62.

7 Harrison LW. Half a lifetime in the management of venereal disease:from chaos to order. Med Illust 1949;3: 318-24.

8 Report of the Departmental Committee of the Prevention of Venereal Disease among the British Troops in India. C. 8379 , paras $13-15$.

9 Welch FH. On aortic aneurysm in the army and conditions associated with it. Med-Chir Trans 1876;41:59-77.

10 McDonagh JER. Venereal diseases. London: Heinemann, 1920:268.

11 Oriel JD. The scars of Venus. London: Springer Verlag, 1996 179

2 Fisher T. Prostitution and the Victorians. Stroud: Sutton Publishing, 1997:x.

3 Acton W Prostitution, considered in its moral, social and sanitary aspects. London: Churchill, 1857:142-3.

14 Mort F. Dangerous sexualities. Medico-moral politics in England since 1830. London: Routledge \& Kegan Paul, 1987:75-6

5 Report of the Committee Appointed to Enquire into the Report of the Committee Appointed to Enquire into the on Prostitution and the Treatment of Venereal Disease, C.7148. 1893:230

16 Davenport-Hines R. Sex, death and punishment, London: Collins, 1990:175-9

17 Report of the Royal Commission upon the Administration and Operation of the Contagious Diseases Acts. Vol II Minutes of Evidence \&c, C.408-I. 1871:540-1.

18 Officers of the Royal Army Medical Corps. A manual of venereal diseases. Oxford: Oxford University Press, 5-40.

19 MacLeod K. Precis of operations performed in the wards of the First Surgeon. Medical College Hospital during the year 1881. Indian Med Gazette 1882;17:113-23.

20 Donovan C. Medical cases from Madras General Hospital:  1905;40:414.

21 Ramachandra Rao MG. A case of granuloma inguinale. Indian Med Gazette 1931;66:21.

22 Lambkin EC. Report on the incidence of venereal diseases in the Army. Proceedings of the Imperial Social Hygiene Congress at the British Empire Exhibition, Wembley. London: 1925:18-23

23 Empire Social Hygiene Year-Book: First Annual Edition London: George Allen \& Unwin, 1934:304-5.

24 Raina BL, ed. Official history of the Indian armed forces in the second world war 1939-45. Medical services preventive medicine. Combined Inter-services Historical Section, India \& Pakistan, 1961:699-716.

25 Narayanrao UB. Problem of venereal diseases in India. Indian 7 Vener Dis 1935;1:3-8.

26 Pereira EDC, Ratnatunga CS. History of venereal disease control in Ceylon. Br f Vener Dis 1965;41:97-106. 